Volume 13 Number 3, July-September 2019: pp. 241-254. Copyright (c) 2019 FIAT JUSTISIA. Faculty of Law, Lampung University, Bandarlampung, Lampung, Indonesia. ISSN: 1978-5186 | e-ISSN: 2477-6238. Open Access: http://jurnal.fh.unila.ac.id/index.php/fiat

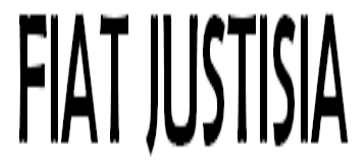

Fiat Justisia is licensed under a Creative Commons Attribution 4.0 International License, which permits unrestricted use, distribution, and reproduction in any medium, provided the original work is properly cited.

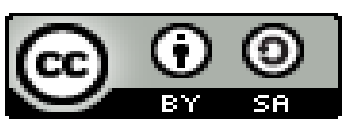

\title{
Siri' Na Pacce Culture in Judge's Decision (Study in Gowa, South Sulawesi Province)
}

\author{
Muhammad Ikram Nur Fuady \\ Islam Negeri Alauddin Makassar, Indonesia \\ ikram.nurfuady@uin-alauddin.ac.id
}

\begin{abstract}
Manimbohoi Village in Gowa District is a part of the Makassar tribe that respects the Siri'naPacce culture. This culture highly upholds shame, honor, dignity, and togetherness as a Cultural Law. During this time, there is often a difference between the Traditional Law of Siri'Na Pacce and Indonesian Positive Law in upholding the material values of criminal acts, so that judges' decisions are difficult to accept by local communities.This study aims to determine the influence of the culture of SirinaPacce' regarding the judge's decision in constructing the criminal offences committed by residents of Manimbohoiwith the decision Number: 66/Pid.B/2012/PN.Sungg.

This study used a normative empirical approach with a descriptivequalitative method that analyses cases of judges' positions and judgments on decisions plus data obtained by interviews with the Adat Officer, Manimbohoi's people, the judge in Sungguminasa District Court.

The results of the study showed that 1)The Siri' Na Pacce as unwritten laws and positive Indonesian law as written laws have the same position in the Republic of Indonesia which can be carried out as long as there is no comparison in the KUHP as Criminal Code; 2)In the decision, the judge has been progressive by imposing a sanction lower than the prosecutor's request indicating that the judge acknowledges Siri 'na Pacce even though it does not include it in writing on the consideration of the points of judges; 3)The weight and lightly of punishments and values of Siri'na Pacce's held by the judge depends on the benefits and feelings held by the judge as a benchmark based on the individual judge's personality; 4)The judge acknowledges the culture of Siri 'Na Pacce as living law but has not been able to put it into judgment as justification, forgiveness, and mitigation reason; 5)Therefore, this Siri'Na Pacce should be maintained Indonesian identity.
\end{abstract}


Keywords: Culture, Siri' Na Pacce, Adat Law, Judge's Decision

How to Cite: Muhammad Ikram Nur Fuady, "Siri' Na Pacce Culture in Judge's Decision (Study in Gowa, South Sulawesi Province)", Fiat Justisia, 13 (3), (2019).

DOI:10.25041/fiatjustisia.v13no3.1684

\section{A. Introduction}

The legal system in Indonesia is currently born with a long historical process. It obtains influence from several legal systems, such as the European Continental Legal System, the Civil Law, the Islamic Law, and the Adat Law. Therefore, in completing a case, a judge must carefully see all sources of law, including Adat law or common law in society. The common law is the values of the local community that had to exist for a long time known as Adat Law or Adatrecht ${ }^{1}$ in order a judge's decision can be accepted and understood by the society.

Adat law which was initially an existing law and able to provide solutions to various problems in the life of the Indonesian people, the more faded the existence of the day. At present, in its empirical reality, there are often many problems that arise in the face of indigenous peoples of Indonesia when customary law deals with positive law. For example, the rise of horizontal conflicts, between indigenous peoples in one area, should be resolved through the role of indigenous peoples' settlement institutions. The crucial problem that arises in daily life is the difference in perception between land tenure by the community based on communal rights and public interests which is a burden and obligation of the state. Another example is the idea that the basis is worthy of an action extended to the domain of Adat law. ${ }^{2}$

In its development, there were decisions by a judge who seemed not to consider the cultural values of the local society, so that the decision was deemed not by the values that live in the community. It is exacerbated by the public's lack of knowledge of the positive legal system making a judicial decision challenging to accept. As one example of the culture of the Indonesian people is the culture of Siri 'naPacce in the Province of South Sulawesi.

South Sulawesi Province consists of four major tribes, namely the Makassar tribe, the Bugis tribe, the Mandar tribe, and the Toraja tribe. Of the four tribes, they have a SirinaPacce which is a cultural value that is used as a

\footnotetext{
${ }^{1}$ Munir Salim, “Adat Recht Sebagai Bukti Sejarah Dalam Perkembangan Hukum Positif Di Indonesia", Al-Daulah Journal, 4 (1), (2015), p. 19.

${ }^{2}$ Lastuti Abubakar, "Revitalisasi Hukum Adat Sebagai Sumber Hukum Dalam Membangun Sistem Hukum Indonesia”, Jurnal Dinamika Hukum, 13 (2), (2013), p. 320.
} 
guideline by the community in living their daily lives. Siri' means embarrassment, which means self-esteem, whereas Pacce means poignant and implies a sense of solidarity and help. ${ }^{3}$

Based on the description, it can be concluded that Siri'Na Pacce is a form of self-esteem, dignity, and sense of belonging as a whole or solidarity of Bugis, Makassar, Mandar, and Toraja ethnic communities and is used as a guide in carrying out daily life and behaving well for the individual itself and the environment. ${ }^{4}$

Then in the context of applicable law in Indonesia, the constitution recognizes that in addition to written law there is also an unwritten law, namely customary law. Whereas according to Article 18B paragraph (2) of the 1945 Constitution ${ }^{5}$, the position of Adat law must still be adjusted to the rules and regulations (written). It is always a gap in the impartiality of national legislation to Adat law.

In the area of South Sulawesi, including parts of Gowa District, which is part of the Makassar tribe, still holds the Siri'naPacce culture. However, the crime rate against lives and bodies in the form of murder and persecution is increasingly prevalent. The crime occurred because it was motivated by various motives of crime such as aggrieve, jealousy and revenge. Usually, the victim has done an act that offended the feelings of the offender, causing resentment and finally a criminal law of persecution or murder.

Crimes of murder often occur in Gowa District, which is also common due to violations of Adat law related to Siri'Na Pacce culture. Adat law on the earth of South Sulawesi is cosmic (maintaining balance of the world) and communal (collective), so as if there are a few disturbances which are considered to damage the balance, then it must be cleaned or purified.

The actual value that is deemed comparable with self-esteem is feasibility in life as a human being who is recognised and treated equally by everyone towards each other. People who do not receive proper treatment from someone feel that their pride is violated. In the Makassar sentence, the person who is treated improperly can say Napasiri'ka. ${ }^{6}$

Inappropriate treatment, which can be in the form of violation of the rights of insult and the like can lead to a strong reaction from the person who is a napakasiri' in the way of murder or other actions that show as a reaction that

\footnotetext{
${ }^{3}$ A. Hamid, Farid, Z. A Mattulada.,Lopa, B., \& C. Salombe, Siri' \&pesse: Harga diri manusia Bugis, Makassar, Mandar, Toraja. Makassar: Pustaka Refleksi, (2007), p. 55.

${ }^{4}$ Mughny Ilman Wali Rusdi., Susanti Prasetyaningrum, "Nilai Budaya Siri'na Pacce dan Perilaku Korupsi”, Indigenous Journal, 13 (2), (2015), p. 73.

${ }^{5}$ Article 18 B Paragraph (2) of the 1945 Constitution: The State recognizes and respects Adat law community units and their traditional rights insofar as they are still alive and in accordance with the development of society and the principle of the Unitary State of the Republic of Indonesia.

${ }^{6}$ Mattulada, Siri’ \&Pacce, Makassar: Pustaka Refleksi, (2009), p. 59.
} 
comes from someone who has a high temper. So that criminal acts of crime that often occur in Gowa District related to the Siri' Na Pacce' violation issue are carried out based on traditional deliberation decisions that can be said to have been planned and carried out in a crowd (mass) by community members.

This action is considered as the implementation of Pacce values and is considered not deviant by the local community although the crime of murder has automatically contradicting with the positive criminal law, namely Kitab Undang-Undang Hukum Pidana (KUHP) as the Criminal Code. Whereas regarding Adat sanctions in the form of murder it is legitimate because it is a decision of the adat leader.

An example is in the case of Decision Number 66/Pid.B/2012/PN. Sungguminasa in Manimbohoi Village, Gowa Regency. This area is an Indigenous village that still holds traditional values in the lives of its people. In this case a resident of Manimbohoi Village named H. Mantang Dg. Naba was charged with committing a criminal act of premeditated murder to residents of another village known to have committed adultery with the wife of the defendant. It offended H. Mantang Dg. Naba seriously that he made villagers attack and kill the victim because Napasiri'ka was in Siri 'na Pacce.

Besides the application of the positive law, another factor that affects the crimes imposed on the accused is the judge's decision. Referring to Article 5 paragraph (1) of Law No. 48 of 2009 about Judicial Power, as stated below:

"Constitutional judges and judges must explore, follow, and understand the legal values and sense of justice that live in their communities".

Thus, it is evident that the role of judges is not only law enforcement but also the enforcer of justice. In making decisions, judges have different opinions both in terms of juridical considerations and sociological considerations but still pay attention to the values of living habits in society. It is because often the decisions handed down by judges are considered not to reflect the values of justice.

Based on the description above, it encourages the curiosity of researchers to study more about the proper application of murder cases that have occurred in Gowa District, South Sulawesi Province (Case Study of Decision Number 66/Pid.B/2012/PN.Sungguminasa).

\section{B. Research Methods}

This study used a normative-empirical approach. A normative approach is an approach through literature study by reading, analyzing legal theories, legislation related to problems in research, particularly the judge's decision in Number 66/Pid.B/2012/PN.Sungg. While the empirical approach is an effort to obtain clarity and understanding of research problems based on existing realities by interviews the Adat Officer, Manimbohoi's people, and judge in Sungguminasa District Court. Data sources were obtained from literature 
studies, observations in villages in Manimbohoi Village and interviews with resource persons then being analyzed qualitatively, then presented descriptively, namely by explaining and describing the problems and their solutions which are strictly related to this research.

\section{Discussion}

In this study, it will be explained in advance about the location of the study, namely Manimbohoi Village, Gowa District, South Sulawesi Province which still holds the value of Siri' $\mathrm{Na}$ Pacce as Adat law and then relates it to the judge's decision Number 66/Pid.B/2012/PN.Sungg. The following is an overview of Adat law in Manimbohoi Village:

\section{Adat Law in Manimbohoi Village}

Based on the results of interviews with the Head of Manimbohoi Village and Adat Figures from Manimbohoi Village, on December 5th, 2013, the following data were obtained:

a. In the Gowa District area, there are only 2 (two) remaining villages that still adhere to the culture of siri 'napacce', namely Manimbohoi Village and Majannnang Village in Parigi District, Gowa District;

b. Culture Siri' Na Pacce applies in the area of Manimbohoi Village and Majannang Village to all people who are in the field of both villages both native and non-native residents;

c. Culture Siri' Na Pacce applies with government law led by Adat Stakeholders and Village Heads;

d. The Siri' Na Pacce as Adat law is in an unwritten form and is only resolved by village judges by deliberation;

e. Adat leaders consist of 12 people who become a kind of adat leader and 3 (three) of them become leaders of traditional village leaders or called Ana'Gallarrang. The leaders of the adat party, which numbered 3 (three) people, were the village judges in deciding on a Siri' Na Pacce case in Manimbohoi Village which in coordination still coordinated with the Village Head, community leaders and the villagers themselves through deliberation;

f. Adat leader figures consisting of 12 (twelve) people have existed from the time of the ancestors chosen based on their lineage. So it can be said that the traditional leaders were the descendants of the Karaengin the past and who are the traditional leaders now are their descendants;

g. In the implementation in the field of law, the people of Manimbohoi Village handed over the problem of criminality always first to the adat leaders, and the adat leaders must coordinate with the village head. In ordinary criminal cases such as theft and fraud, adat officials hand over the matter to the village head to be resolved legally by the police. Whereas 
specifically for siri 'na pacce' things, then this must be determined by the adat stakeholders.

h. Adat leader figures consisting of 12 (twelve) people have their respective duties in their government. It is the same as the cabinet system in the government. Each task of the adat stakeholders is:

Table 1.Adat Stakeholder / Officer and Their Role

\begin{tabular}{|c|l|l|}
\hline No & $\begin{array}{c}\text { Adat Stakeholder / } \\
\text { Officer }\end{array}$ & \multicolumn{1}{|c|}{ Role } \\
\hline 1 & $\begin{array}{l}\text { Ana' Gallarrang : } \\
\text { Galla' } \text { Toa }\end{array}$ & $\begin{array}{l}\text { Become a Village Judge and Executor of Adat } \\
\text { Sanctions }\end{array}$ \\
\hline 2 & $\begin{array}{l}\text { Ana' Gallarrang : } \\
\text { Galla' } \text { Tengah }\end{array}$ & $\begin{array}{l}\text { Become a Village Judge and Executor of Adat } \\
\text { Sanctions }\end{array}$ \\
\hline 3 & $\begin{array}{l}\text { Ana' Gallarrang : } \\
\text { Galla' } \text { Muda }\end{array}$ & $\begin{array}{l}\text { Become a Village Judge and Executor of Adat } \\
\text { Sanctions }\end{array}$ \\
\hline 4 & Pinatinana & Take care of things about agriculture \\
\hline 5 & Anrongparasangang & Take care of all things about the population \\
\hline 6 & Sanro & Doctor or shaman \\
\hline 7 & Suro & $\begin{array}{l}\text { As Public Relations who always monitor the } \\
\text { condition of the village }\end{array}$ \\
\hline 8 & Guru & Take care of matters relating to religion \\
\hline 9 & Tubarani & $\begin{array}{l}\text { Commander of the village (being the first } \\
\text { person to step down in the face of chaos) }\end{array}$ \\
\hline 10 & Aganna & Manage and organize village youth \\
\hline 11 & Bilirarang & Traditional ritual preparation coordinator \\
\hline 12 & Doke' & $\begin{array}{l}\text { Take care of everything about land in the } \\
\text { village }\end{array}$ \\
\hline
\end{tabular}

Source: Interviews with the Head of Manimbohoi Village and Adat Figures from Manimbohoi Village, on December 5th, 2013

i. The actions included in the violation of siri 'na pacce' in Manimbohoi village are:

1) Violations of customs, such as marriage. For example, if the groom arrives late at the bride's house, a fine will be imposed depending on how long the groom is late. The fine must be paid by the groom immediately before the commencement of the marriage contract in the form of money or rice;

2) Violations of traditional ritual events such as thanksgiving for the results of harvest or every season change, a ritual will be held asking for sustenance in the village. If there are parties who disrupt the 
method, then it includes violations of siri 'na pacce', so that they will usually be given fines and even killed;

3) Silariang, is a man who runs away from someone else's daughter without the permission of the girl's parents. If this happens, the adat party can reconcile the two families where the men must pay compensation to the girl at the request of the woman. If this cannot be fulfilled, the male and female partner must leave the village and cannot be accepted again. If this cannot be fulfilled, the man and the girl will be killed because their actions include violations of siri 'na pacce';

4) Mallariang, which is a man running away from someone else's wife. If this happens, the adat authorities will order to arrest the man and will be killed as a sanction;

5) Adultery, which is intercourse between men and women who are not husband and wife, where a man or woman has been married before. The penalties are that men and women who commit zina are expelled for 7 descendants after them, this is a definition of "forever". They are no longer accepted in the village, while if this is not done, then both will be killed;

6) Unwed pregnancy. If this happens, the adat authorities will impose fines on men if they are responsible for their actions. If men do not want to be accountable, then the man will be killed.

7) The indicators of an action that includes violations of siri 'na pacce' in the area of Manimbohoi Village are:

a) Performing operations aimed at disrupting traditional village rituals;

b) Acts that are insulting to Adatstakeholders;

c) Activities that violate the norms of decency which are an essential part of Siri' Na Pacce;

d) Events that can disrupt the balance of the village or the right name of the town because there is a belief that if things happen that violate Siri 'Na Pacce, then there will be no sustenance from God, so it must be immediately rebalanced.

\section{Adat Sanctions of Siri' Na Pacce}

The forms of Adat sanctions imposed by Ana' Gallarrang as Adat leaders in the village of Manimbohoi are:

a. A Fine Sanction

Requests by the aggrieved party impose sanctions for these fines. In its implementation, Adat leaders can intervene to strive for the achievement of peace by reducing the value of penalties requested; Examples of acts that are subject to fines sanctions are crossing and violations of traditional rituals. 
b. Sanctions for Expulsion from the Village for 7 (Seven) Descendants or Forever

Sanctions in which the litigant will be expelled and not accepted into the village area for 7 (seven) derivatives or forever, including his children and grandchildren and so on. Usually this sanction is given for massive violations of Siri 'Na Pacce, for example Zina and Mallariang. Determination of expulsion for 7 (seven) derivatives or forever is submitted to the results of Adat deliberations by Adat stakeholders. If this is not done, the perpetrators of Siri 'Na Pacce offenders can be killed.

\section{c. Sanctions for Death or Killed}

This sanction is the most substantial sanction. The death sanction or death penalty is taken if there is no peace, does not fulfil the decision of the adat leader or violates the Siri'Na Pacce severe which cannot be forgiven and disturbs the balance of the village. It was decided through deliberations and carried out by adat stakeholders.

\section{Influence of Siri 'Na Pacce Culture in the Judge's Decision}

The public prosecutor charged the defendant with primary charges, Article 340 Jo. Article 55 paragraph (1) 2nd Criminal Code concerning premeditated murder, Subsidies Article 338 Jo. Article 55 paragraph (1) of the Criminal Code concerning ordinary killings, and the second primary charge is Article 160 of the Criminal Code, in subsidiary of Article 160 Jo. Article 2 paragraph (1) of the Criminal Code concerning acts that are publicly spoken or written with incitement to do something that can be punished, against public authority by force or so that you do not want to be according to legal regulations or legal orders.

Then the public prosecutor submitted a letter of indictment No. Reg: PDM-SNGGU /02/2012 dated May 24, 2012, which demands that the defendant H. Mantang Dg. Naba bin De'ke Dg. Beta is proven guilty of committing a crime by providing an opportunity for means or information to deliberately recommend a criminal act of murder planned as regulated and threatened with criminality in article 340 of the Criminal Code jo. Article 55 paragraph (1) of the Criminal Code, in the first primary charge. Then it sentenced the defendant H. Mantang Dg. Naba bin De'ke Dg. Beta, therefore, is subject to imprisonment for 16 (sixteen) years minus the period of a detainee who has been convicted during his detention.

The Sungguminasa District Court judge who decided the case Number 66/Pid.B/2012/ PN.Sungguminasa gave a guilty verdict to the defendant for the crime of planned killing as Article 340 of the KUHP with imprisonment for 12 (twelve) years. In its decision, there are judges' considerations which the researchers carefully examine and analyze are as follows: 


\section{a. The Judges' Decision Depends On The Value And Feeling Of The Judge}

Adat criminal law gets a place through Emergency Law No. 1 of 1951. In Article 5 paragraph (3) letter $b$ of this Act describes Adat law that has no equal in the Criminal Code, Adat law that is comparable in the Criminal Code, and Adat sanctions. Adat sanctions can be used as the principal or primary criminal penalties by the judge in examining and deciding acts which according to existing law are considered as criminal acts that have no equal in the Criminal Code. Based on this, the criminal acts of premeditated murder stipulated in Article 340 of the Criminal Code continue to be used and accepted by the judge as a primary criminal offence.

However, there are other examples of cases such as one of the decisions that respect customary law, according to Prof. Nyoman Serikat, is the decision of the Supreme Court No. 984 K / Pid / 1996 dated January 30, 1996. In this decision, the panel of judges stated if the perpetrator (dader) of adultery had been sanctioned by adat or received anAdat reaction by the traditional village stakeholders, where Adat law was still respected and lived fertile, the demands of prosecutors must be declared unacceptable ${ }^{7}$.

Whereas in the decision Number 66 / Pid.B / 2012 / PN.Sungguminasa, the charges and demands of the prosecutor remain accepted then the defendant is given a guilty verdict by the judge. This is the focus of this study's study of the clash between criminal values in Adat Law and Positive Law applicable in Indonesia.

Therefore, according to the results of the researchers' analysis, judges cannot immediately ignore the favorable laws that apply because of the existence of Adat law as long as the criminal provisions have been regulated and there is a comparison to the Criminal Code as a penal code. Judges must still refer to the Criminal Code to provide primary and additional criminal penalties, while the severity and severity of punishment depend on the value and feeling of the judge as a benchmark that depends on the individual judge.

If the judge has high values and feelings for the amount of customary law, the judge will tend to give a lighter verdict and vice versa. So that the decision Number 66 / Pid.B / 2012 / PN.Sungguminasa, according to the researcher that the judge who takes a lower sanction than the prosecutor's demands has substantial value and feeling towards the importance of Siri 'Na Pacce's Adat law as "living law" in Manimbohoi Village.

\section{b. Judges' Decisions Are Progressive}

\footnotetext{
7 Putusan-Putusan yang Menghargai Pidana Adat.(2016). available online from https://www.hukumonline.com/berita/baca/lt5746f66360762/putusan-putusan-yangmenghargai-pidana-adat/ [AccesedJuly 27th 2019].
} 
Sanctions of imprisonment to the accused during the twelve (12) years.It is lighter than the demands of the public prosecutor, namely that for 16 (sixteen) years it is considered by the living values and legal culture of the defendant as part of the community of South Sulawesi, especially in Gowa District, namely Siri' Na Pacce.

Siri' and Pacce is what directs people's behavior in daily life, as the "driving force" of their society in manifesting (manifesting) their cultural patterns and social systems. ${ }^{8}$

So, the Siri' Na Pacce culture, if you want to be associated with court decisions, can it be considered or not, depending on who decides. The sanction reduction from the right one is relatively no size. Moreover, the Siri' $\mathrm{Na}$ Pacceis more based on feelings. ${ }^{9}$

According to Nonet and Selznick in Theory of Responsive Law that is responsive legal concepts emphasized the importance of the meaning of policy goals and juridical elaboration and policy reactions as well as the importance of participation of groups and individuals involved in policymaking. Law that directs the realization of the values contained in the ideals and juridical will of the entire community. These values are not things that have become government policy, but these values must be reflected in the practice of the use and implementation of the law so that in their appreciation these values can give direction to political and legal life. ${ }^{10}$

Responsive legal conception was constructed by two schools of law which were later well known for its development. The thinking of Satjipto Rahardjo with his progressive legal concept which states that code should be able to keep up with the times can answer changes with all the bases in it, and be ready to serve the community by relying on aspects of morality from human resources to law enforcement itself. His belief in the sociology of law as a tool in deconstructing legal thinking increasingly crystallized the idea that the responsive legal conception initiated by Philippe Nonet and Selznick was indeed supported by sociological jurisprudence schools which provided the ability for judicial institutions to more thoroughly and intelligently consider the social facts in which the law it processes and is applied. ${ }^{11}$

\footnotetext{
${ }^{8}$ Hamid, Abdullah, dkk, SIRI' (KearifanBudaya Sulawesi Selatan), Jakarta: Lembaga Kesenian Sulawesi Selatan-DKI Jakarta dan Badan Kerjasama Kesenian Indonesia-DKI-, (2006), p. 314. ${ }_{9}^{9}$ Mappaselleng, Nur Farida, "Penegakan Hukum Pidana Terhadap Delik Pembunuhan Yang Bermotif Siri' di Sulawesi Selatan”,Tesis. Surabaya Faculty of Law, Airlangga University, p. 43.

${ }^{10}$ Konsep Hukum Responsif. (2012). available online from https://www.academia.edu/36399283/HUKUM_RESPONSIF_Philippe_Nonet_dan_Philip_Se lznick, [AccesedNovember 30 ${ }^{\text {th }}, 2013$ ]

${ }^{11}$ Orinton, Perdebatan Teori Hukum Responsif. Available online fromhttp://orintononline.blogspot.com/2013/02/perdebatan-teori-hukum-responsif.html. [Accesed November 29 , 2013].
} 
Therefore, the legal cultural value of the community of Manimbohoi Village, which is an existing law as one of the legitimate sources should be considered in its belief by the Panel of Judges in giving a verdict. In this case, the defendant, H. Mantang Dg. Naba only carried out Adat orders even though they were carried out in a rash manner.

\section{c. Siri 'Na Pacce Cultureas mitigation reason in Judge's Decision}

Indonesian positive law only recognizes justification reasons and forgiving reasons. In further elaboration, we have not found that a community law culture such as Siri' Na Pacce is part of justification reasons and forgiving reasons. It is one of the clashes between favorable laws that apply nationally and local rules.

In the judge's decision some things were burdensome and mitigating, the Panel of Judges did not include the Siri' Na Pacce motive element explicitly in the decision. While based on the results of interviews with Yoga who was one of the member judges who examined the case in the Sungguminasa District Court on December 11, 2013, he said:

"Provisions on Adat law can be implemented when not regulated by our positive law. The actions carried out by the defendant, H. Mantang Dg. Naba did not erase the mistakes he made, but could be included as things that alleviated his actions".

A statement issued by the judge in a different interview with the implementation of its decision because there was no motive Siri' Na Pacce as outlined in the decision as mitigating factors.According to the researcher, the Siri' Na Pacce motive cannot erase the mistakes of the perpetrators, so the Siri' Na Pacce' motive cannot be used as a criminal excuse, either as justification or forgiving reasons. Criminal acts with a Siri' Na Pacce motive can only be a mitigating element.

It is in line with the results of an interview with Mahyuti who was one of the judges of the Makassar District Court on January 17th, 2013, stating that: ${ }^{12}$

"In practice, if there are things that alleviate crime. Then the judge will not decide the maximum sentence to the defendant".

Thus, culture Siri 'Na Pacce, when you want to be associated with the decision of the court, whether it can be considered or not, depending on who decides. The sanction reduction from the right one is relatively no size because the Siri' Na Pacce is more based on feelings.

Based on Emergency Law No. 1 of 1951 about Provisional Measures to Organize the Unity of the Power and Event Arrangements of Civil Courts in

12 Eka Hardianti, "Tinjauan Yuridis Terhadap Tindak Pidana Pembunuhan Berencana dan Penganiayaan Yang Mengakibatkan Luka Berat", Thesis Faculty of Law, Hasanuddin University, (2013), p. 138. 
Article 5 Number 3 Part b, it can be concluded that after the Adat crimes committed will be processed and given criminal sanctions in accordance with Adat law as long as there is no comparison with civil criminal law, namely the KUHP as the Criminal Code. If there is a comparison in the KUHP, the sanctions to be given are adjusted to the KUHP, not Adat law.

It confirms that the crime with Siri' $\mathrm{Na}$ Pacce motives which is a manifestation of the legal culture of the people of South Sulawesi, especially in Gowa District, cannot erase its mistakes and can only be a mitigating thing and its benchmarks return to the judge's confidence.

Based on this, it is known that the judge acknowledged the culture of Siri' $\mathrm{Na}$ Pacce as existing law, but had not been able to express it explicitly into the judgment of the judge as justification, forgiveness, and mitigation.

\section{Conclusion}

Based on the results of the researchers' analysis, it was concluded that:

1. The Siri' Na Pacce laws as unwritten laws and positive Indonesian law as written laws have the same position in the State of Indonesia;

2. In its implementation, criminal acts in the Adat Law of Siri 'Na Pacce can be implemented based on Emergency Law No. 1 of 1951 about Provisional Measures to Organize the Unity of Power and Event Arrangements of Civil Courts as long as there is no comparison in the Criminal Code;

3. In the decision Number 66 / Pid.B / 2012 / PN.Sungguminasa, the judge has been progressive by imposing a sanction lower than the prosecutor's request indicating that the judge acknowledges and accommodates the the value of Siri' Na Pacce's Adat law even though it does not include it in writing at the point consideration of judges. It is reflected in the taking of consideration in Article 340 of the KUHP and a sanction of 12 (twelve) years in prison which according to researchers has approached justice. This shows that the judge has seen the values that live in the community while the Adat law regarding Siri' Na Pacce is still alive and held firmly by the people of Manimbohoi Village.

4. The weight and lightly of punishments and values held by the judge on the decision Number 66 / Pid.B / 2012 / PN.Sungguminasa depends on the values and feelings held by the judge as a benchmark based on the individual judge's personality;

5. The judge acknowledged the culture of Siri' $\mathrm{Na}$ Pacce as an existing law but had not been able to put it firmly into the judgment of the judge as justification, forgiveness, and mitigation. Based on the results of interviews with the judges who handled the case, the judges argued that the criminal acts with Siri' Na Pacce motives could be mitigating things, but in the decisions made, there was no explicitly stated Siri' Na Pacce motives in terms of mitigation; 
6. Therefore, Siri' naPacce as a culture, custom, and Adat law for the people of South Sulawesi, including in Gowa District, existed long before the KUHP as Criminal Code came into effect. Therefore, this Siri' Na Pacce should be maintained and practiced as a community identity and Indonesian identity.

\section{Acknowledgement}

This study was independent research that was supported by Bidik Misi Scholarship from Indonesian Government. This research was assisted by Prof. Dr. SyukriAkub, S.H., M.H. and Kaisaruddin Kamaruddin, S.H. in giving opinions and instructions, so that they can be completed properly.

\section{A. Book}

\section{Bibliography}

Hamid, A., Farid, Z. A., Mattulada.,Lopa, B., \& Salombe, C. (2007). Siri' \& Pesse: Harga Diri Manusia Bugis, Makassar, Mandar, Toraja. Makassar: Pustaka Refleksi.

Hamid, Abdullah, dkk. (2006). SIRI’ (Kearifan Budaya Sulawesi Selatan). Jakarta: Lembaga Kesenian Sulawesi Selatan-DKI Jakarta dan Badan Kerjasama Kesenian Indonesia-DKI-Jakarta.

Mattulada. (2009). Siri’ \&Pacce'. Makassar: Pustaka Refleksi.

\section{B. Journal and Thesis}

Eka Hardianti, "Tinjauan Yuridis Terhadap Tindak Pidana Pembunuhan Berencana dan Penganiayaan yang Mengakibatkan Luka Berat", Thesis Faculty of Law, Hasanuddin University, (2013).

http://dx.doi.org/10.20884/1.jdh.2013.13.2.213.

Lastuti Abubakar, "Revitalisasi Hukum Adat Sebagai Sumber Hukum Dalam Membangun Sistem Hukum Indonesia", Dinamika Hukum Journal, 13 (2), (2013).

doi : http://dx.doi.org/10.24252/ad.v4i1.1504.

Mappaselleng, Nur Farida, "Penegakan Hukum Pidana Terhadap Delik Pembunuhan yang Bermotif Siri' di Sulawesi Selatan", Thesis Faculty of Law, Airlangga University.

Mughny Ilman Wali Rusdi, Susanti Prasetyaningrum, "Nilai Budaya Siri'na Pacce dan Perilaku Korupsi”, Indigenous Journal, 13(2),(2015). http://dx.doi.org/10.23917/indigenous.v13i2.2619.

Munir Salim, "Adat Recht Sebagai Bukti Sejarah Dalam Perkembangan Hukum Positif di Indonesia”, Al-Daulah Journal, 4 (1), (2015). 


\section{World Wide Web}

Konsep Hukum Responsif. (2012). available online from https://www.academia.edu/36399283/HUKUM_RESPONSIF_Phili ppe_Nonet_dan_Philip_Selznick, [Accesed November 30 ${ }^{\text {th }}, 2013$ ]

Orinton. Perdebatan Teori Hukum Responsif. Available online fromhttp://orintononline.blogspot.com/2013/02/perdebatan-teorihukum-responsif.html. [Accesed November 29 ${ }^{\text {th }}, 2013$ ].

Putusan-Putusan yang Menghargai Pidana Adat. (2016). available online fromhttps://www.hukumonline.com/berita/baca/lt5746f66360762/pu tusan-putusan-yang-menghargai-pidana-adat/ [Accesed July $27^{\text {th }}$, 2019]

\section{Legistation}

1945 Constitutions of Republic of Indonesia.

Emergency Law Number 1 of 1951 about Temporary Actions for Handling Unity Of Authority And Events Of Civil Courts.

Law Number 1 of 1946 about Kitab Undang-Undang Hukum Pidana or Criminal Code (KUHP).

Law Number 48 of 2009 about Judicial Power. 